\title{
Genotypic and phenotypic differences between Baltic and North Sea populations of Mytilus edulis evaluated through reciprocal transplantations. III. Physiology
}

\author{
Michael Tedengren ${ }^{1}$, Carl André ${ }^{1}$, Kerstin Johannesson ${ }^{2}$, Nils Kautsky ${ }^{1}$ \\ ${ }^{1}$ Department of Zoology and Askö Laboratory, Institute of Marine Ecology, University of Stockholm, S-106 91 Stockholm, \\ Sweden \\ ${ }^{2}$ Tjärnö Marine Biological Laboratory, PL. 2781 S-452 00 Strömstad, Sweden
}

\begin{abstract}
Mussels Mytilus edulis L., aged 1 yr, were transplanted from a low saline regime $(6$ to $7 \%$ S, northern Baltic proper) to a high saline regime (20 to $30 \% \mathrm{~S}$, North Sea). Physiological responses of these mussels, after 1 mo and 1 yr of acclimatisation, were compared to those of native North Sea mussels and allele frequencies for 2 polymorphic loci (Pgi and Pgm) in the populations were scored. Oxygen consumption, ammonia excretion, $\mathrm{O} / \mathrm{N}$ ratios, and clearance rate of transplanted Baltic mussels approached those of native North Sea mussels, indicating that these metabolic parameters are to a major extent regulated by physiological adaptations to environmental differences between the Baltic and North Seas. However, after 1 yr, significantly higher $\mathrm{NH}_{4}-\mathrm{N}$ excretion and lower $\mathrm{O} / \mathrm{N}$ ratios were observed in mussels of Baltic origin. A lower clearance rate and consequently lower scope for growth was observed in Baltic mussels. This may be due to a smaller gill area, resulting from a genetically induced more elongate shell shape, typical for Baltic mussels, that still remained after 1 yr of acclimatisation. The genetic composition in Pgi and Pgm, 2 loci coding for enzymes which are central to the metabolic rate of cellular processes, differed between the native populations, probably due to differential selection, and part of the observed physiological differences between mussels from the 2 seas may be determined by genotypic factors acting directly on metabolic pathways.
\end{abstract}

\section{INTRODUCTION}

Adaptation to brackish-water conditions, such as those in the Baltic Sea, has created considerable morphological and physiological differences in animal and plant species which also occur in seawater. In the blue mussel Mytilus edulis, e.g. growth rate, maximum size and morphology of shells and soft parts differ between low saline (Baltic) and marine (North Sea) populations (Remane 1971, Kautsky 1982, Kautsky et al. 1990 [companion paper]). Tedengren \& Kautsky (1986) also found differences in physiological parameters and suggested that Baltic mussels had a less favourable energy metabolism due to the low salinity of the environment, and concluded that this could contribute to the lower growth rate and smaller maximum size compared to North Sea mussels.

Other studies have elucidated the endogenous basis for intraspecific variation for several physiological parameters in a variety of plant and animal species. In many organisms multiple-locus heterozygosity has been found to correlate significantly with certain fitness parameters (review by Mitton \& Grant 1984). Much work has been focused on marine bivalves in this respect, and heterozygosity and growth rate were found to be positively correlated in Crassostrea virginica (Singh \& Zouros 1978, Zouros et al. 1980) as well as in Mytilus edulis (review by Koehn \& Gaffney 1984). The contribution of individual loci in this relationship was thought to be additive. Recent work by Koehn et al. (1988) has, however, demonstrated differential contributions of different loci to the heterozygosity/growth rate relationship in Mulinia lateralis. A number of studies connect other metabolic parameters to heterozygosity. They include standardised oxygen uptake (Koehn \& Shumway 1982) and weight loss (Rodhouse \& Gaffney 1984) during starvation in C. virginica, and oxygen uptake during starvation (Diehl et al. 1985) and protein turnover (Hawkins et al. 1986) in M. edulis. 
In the present study we investigated to what extent the physiological differences between the populations from the low-saline Baltic Sea and the high-saline North Sea, recorded by Tedengren \& Kautsky (1986), are environmentally induced (non-genetic differences) or inherited characteristics of the population (genetic differences). We have compared 'scope for growth', filtration rate and other physiological parameters in Baltic mussels transplanted and acclimatised to the North Sea environment, with that of native North Sea mussels. This paper thus describes an experiment to assess the effect of genotypic differences on metabolic rates in Mytilus edulis $\mathrm{L}$. The genetic variability, growth rate and morphological differences between the 2 populations are discussed in Parts I and II of this series (Kautsky et al. 1990, Johannesson et al. 1990, respectively).

\section{MATERIAL AND METHODS}

Reciprocal transplantations. In July 1986 a large number of mussels (ca 40000 ) of about 12 mo age and of small size $(4.0 \pm 1.5 \mathrm{~mm})$ were collected from ropes at $9 \mathrm{~m}$ depth near the Askö Laboratory, northern Baltic proper $\left(58^{\circ} 49^{\prime} \mathrm{N}, 19^{\circ} 39^{\prime} \mathrm{E}\right)$ and transferred to Tjärnö Marine Biological Laboratory, on the North Sea $\left(58^{\circ} 53^{\prime} \mathrm{N}, 11^{\circ} 09^{\prime} \mathrm{E}\right)$. The mussels were then stepwise acclimatised over $1 \mathrm{wk}$ from $6.5 \% \mathrm{~S}$ to $28.0 \% \mathrm{~S}$ (ambient salinities at respective sites). This was done in the laboratory by raising salinity 3 to $4 \% \mathrm{~d}^{-1}$ in aerated 501 tanks by adding seawater until a salinity level of $28 \%$ was attained. No mortality was observed within the transplanted population during this phase. Mussels were then suspended at $9 \mathrm{~m}$ depth, side-by-side with native North Sea mussels of the same age but of larger size $(10.0 \pm 2.0 \mathrm{~mm})$. Ropes with reference mussels were left at Askö to enable comparisons. One year after transplantation of Baltic mussels, in July 1987, mussels from both populations were collected and comparative studies on their physiological status and genetic composition were performed.

In July 1988 a further batch of 1-yr-old Baltic mussels was moved to the North Sea and, following the method described, acclimatised for 1 mo to the higher salinity before being used in a repeat set of experiments in August 1988. Data on age, length and biomass of the mussels used in the experiments as well as the length of time of acclimatisation are given in Table 1

Physiological measurements. Experiments were performed at the Tjärnö Marine Biological Laboratory, Sweden, in July 1987 and August 1988. Mussels of the same size from the 2 populations were sampled from the acclimatisation site at $9 \mathrm{~m}$ depth and placed in the experimental chambers in running seawater of ambient salinits (28 to $30 \% \mathrm{~S})$ and temperature $\left(12^{\circ} \mathrm{C}\right)$ in a constant-temperature room with subdued light for a minimum of $24 \mathrm{~h}$ in order to adapt to experimental conditions.

The physiological measurements were performed in 0.51 airtight chambers, with one specimen placed in each of 16 (1987) or 10 (1988) chambers with airsaturated filtered seawater ( 28 to $30 \%$ S). There were also 2 control chambers without mussels. In 1988 4 replicate experiments were conducted. The chambers were kept in a temperature-controlled water bath and carefully stirred by means of magnetic stirrer bars. Only mussels that were active throughout the experiments were included in the analysis. All physiological rates were converted to mass-specific rates for $1 \mathrm{~g}$ mussels (shellfree dry weight) by use of appropriate weight exponents (b) in the allometric equation (filtration rate $b=0.4$, oxygen consumption $b=0.65$, ammonia excretion $b=0.65$ ) (cf. Winter 1978, Widdows \& Johnson 1988).

Respiration rate. The rate of decline in oxygen partial pressure was measured for $2 \mathrm{~h}$, employing a modified polarographic oxygen electrode. Respiration was expressed as mg oxygen consumed per $g$ shellfree dry weight per hour.

Table 1. Mytilus edulis. Shell length, age, biomass and acclimatisation time of mussels transplanted from the Baltic Sea compared to that of mussels native to the North Sea (mean \pm SE)

\begin{tabular}{|lcccc|}
\hline & & & & 1988 \\
& North Sea & Baltic Sea & North Sea & Baltic Sea \\
\hline $\begin{array}{l}\text { Age of mussels at time of trans- } \\
\text { plantation (mo) }\end{array}$ & 12 & 12 & 12 & 12 \\
Length at time of transplantation (mm) & $10.0 \pm 2.0$ & $4.0 \pm 1.5$ & $11.0 \pm 1.5$ & $5.5 \pm 1.0$ \\
Acclimatisation time (mo) & 12 & 12 & 1 & 1 \\
Age at experimental use (mo) & 24 & 24 & 13 & 13 \\
Length at experimental use (mm) & $49.8 \pm 1.3$ & $45.8 \pm 0.8$ & $21.0 \pm 0.4$ & $20.7 \pm 0.5$ \\
Biomass at experimental use & 0.767 & 0.469 & 0.050 & 0.061 \\
(g shellfree dry wt) & \pm 0.078 & \pm 0.060 & \pm 0.003 & \pm 0.009 \\
\hline
\end{tabular}


Ammonia excretion. Water samples were collected from the respiration study, and from the controls and analysed for $\mathrm{NH}_{4}-\mathrm{N}$ using the phenol-hypochlorite method according to the New Baltic Manual (Carleberg 1972).

Ammonia excretion was expressed as $\mu \mathrm{g} \mathrm{NH}_{4}-\mathrm{N}$ excreted per g shellfree dry weight per hour.

$\mathrm{O} / \mathrm{N}$ ratio. The ratio between consumed oxygen and excreted ammonia (in atomic equivalents) was calculated. This ratio decreases with lower salinity, probably as the result of higher rates of protein catabolism relative to carbohydrate and lipid metabolism (Bayne 1973), which is generally indicative of a stressed condition (Bayne et al. 1976b, Bayne \& Scullard 1977, Widdows 1978b, Bayne et al. 1985, Tedengren \& Kautsky 1986, 1987).

Feeding rate. The chambers were filled with filtered seawater with suspended Pyramimonas sp. (Chlorophycea) phytoplankton culture at a concentration of 15000 cells per ml. Clearance rate, defined as the volume of water cleared of suspended particles per unit time and biomass, was determined using an Elzone 80 XY particle counter with a $48 \mu \mathrm{m}$ tube orifice diameter. Samples were taken at the start of the experiment and at 20 or 30 min intervals; 3 replicate counts were made on each sample. Clearance rate was calculated according to the formula:

$$
\begin{gathered}
\text { Clearance rate }\left(\lg ^{-1} \mathrm{~h}^{-1}\right)=\left(\ln \mathrm{C}_{\mathrm{g}}-\ln \mathrm{C}_{0}\right)- \\
\left(\ln \mathrm{C}_{1}-\ln \mathrm{C}_{0}\right) \mathrm{VT}^{-1} \mathrm{~B}^{-1}
\end{gathered}
$$

where $\mathrm{C}_{0}=$ cell concentration at time $\mathrm{T}_{0} ; \mathrm{C}_{1}=$ cell concentration at time $\mathrm{T}_{1 i} \mathrm{C}_{\mathrm{g}}=$ cell concentration in chambers without mussels at time $T_{1 i} \mathrm{~V}=$ volume of suspension; $\mathrm{T}=$ time elapsed between readings; and $\mathrm{B}=$ shellfree dry weight of the mussel.

Absorption efficiency. Absorption efficiency was determined according to the ratio method of Conover (1966). The faeces produced by the mussels during the filtration studies, as well as a number of algae cells, were collected and filtered onto washed and pre-ashed GFC filters. Each filter was washed, dried and weighed, ashed and weighed again. The ratios of the ashfree dry weight of food and faeces were used in the Conover ratio. Faeces from each population were pooled.

Energy budget. Physiological rates were converted into energy equivalents $\left(\mathrm{J} \mathrm{g}^{-1} \mathrm{~h}^{-1}\right)$ and used to construct an energy budget for each individual mussel (Widdows \& Johnson 1988), according to the balanced energy equation, and to calculate 'scope for growth' (Warren \& Davis 1967. Widdows 1978b. Widdows et al. 1981). This equation is as follows:

$$
\mathrm{C}=\mathrm{P}+\mathrm{R}+\mathrm{U}+\mathrm{F}
$$

where $\mathrm{C}=$ total consumption of energy; $\mathrm{P}=$ energy available for production of both somatic tissue and gametes ('scope for growth'); $\mathrm{R}=$ respiratory heat loss; $\mathrm{U}=$ energy lost as excreta; and $\mathrm{F}=$ faecal energy loss. Scope for growth may be expressed as:

$$
\mathrm{P}=\mathrm{A}-(\mathrm{R}+\mathrm{U})
$$

where $\mathrm{A}=$ energy absorbed from the food $(\mathrm{C} \times$ absorption efficiency). $C$ is given by clearance rate $\left(\mathrm{l}^{-1} \mathrm{~h}^{-1}\right)$ $\times$ (mg Pyramimonas $1^{-1}$ ) $\times$ energy content of the algae $\left(22.7 \mathrm{~J} \mathrm{mg}^{-1}\right) . \mathrm{R}=14.0 \mathrm{~J}(\mathrm{mg} \mathrm{O})^{-1}, \mathrm{U}=19.4 \mathrm{~J}$ $\left(\mathrm{mg} \mathrm{NH}_{4}-\mathrm{N}\right)^{-1}$.

Statistical analysis. Student's t-tests were used to test for differences in responses between populations within each year.

Genetic analysis. A small piece of the hepatopancreas was taken from each individual mussel used in. the 1988 experiment and the genomes for the 2 enzyme systems phosphoglucose isomerase (PGI) and phosphoglucomutase (PGM) were assayed by horizontal starch gel electrophoresis for each specimen separately, according to standard methods.

\section{RESULTS}

In the 1987 experiments, mussels were 2 yr old and the transplanted population had been in the highsaline regime for $1 \mathrm{yr}$. The length of the mussels originating from the Baltic then matched that of native North Sea mussels and the 2 groups of mussels were of equal length ( 45 to $50 \mathrm{~mm}$ ) at the time of the experiments. As shown in Table 1, however, they differed in weight due to the more elongate growth form typical of Baltic mussels (cf. Kautsky et al. 1990). In 1988 the experimental mussels were 13 mo old and the transplanted group had been acclimatised to high salinity for only about $1 \mathrm{mo}$. The transplanted and the native mussels were of about the same age, length and biomass at this time (Table 1).

The physiological measurements summarized in Table 2 show that there were no trends or significant differences in the rates of oxygen uptake between any of the transplanted Baltic populations and the North Sea mussels. Whilst the respiration rate in 1988 for 13mo-old mussels was $1.55 \pm 0.14 \mathrm{mg} \mathrm{O}_{2} \mathrm{~g}^{-1} \mathrm{~h}^{-1}$ for native mussels and $1.37 \pm 0.21$ for transplanted mussels, corresponding 24-mo-old mussels in 1987 gave rates of $0.95 \pm 0.19$ for native and $1.17 \pm 0.14 \mathrm{mg} \mathrm{O}_{2}$ $\mathrm{g}^{-1} \mathrm{~h}^{-1}$ for transplanted mussels.

Ammonia excretion of the Baltic mussels was significantly higher than that of North Sea mussels in 1987 $\left(21.4 \pm 1.3\right.$ and $10.7 \pm 1.7 \mu \mathrm{g} \mathrm{NH}_{4}-\mathrm{N} \mathrm{g}^{-1} \mathrm{~h}^{1}$, respectively, $\mathrm{p}<0.0006$ ). For the smaller mussels used in 1988 ammonia excretion was higher than in $1987,106 \pm 6.2$ for native compared to $114 \pm 10.2 \mu \mathrm{g} \mathrm{NH}_{4}-\mathrm{N} \mathrm{g}^{-1} \mathrm{~h}^{-1}$ for 
Table 2. Mytilus edulis. Physiological rates of mussels transplanted from the Baltic Sea and acclimatised to North Sea conditions compared to native North Sea Inussels. Comparisons within years only. (mean $\pm S E$ )

\begin{tabular}{|c|c|c|c|c|c|c|c|c|c|c|}
\hline & $\begin{array}{l}\text { No. of } \\
\text { replicates }\end{array}$ & $\begin{array}{l}\text { Clearance } \\
\left(1 \mathrm{~g}^{-1} \mathrm{~h}^{-1}\right)\end{array}$ & $\begin{array}{c}\text { t-test } \\
(p \text {-value })\end{array}$ & $\begin{array}{l}\text { Absorbtion } \\
\text { efficiency }\end{array}$ & $\begin{array}{c}\text { Respiration } \\
\left(\begin{array}{c}\mathrm{mg} \mathrm{O}_{2} \mathrm{~g}^{-1} \\
\mathrm{~h}^{-1}\end{array}\right.\end{array}$ & $\begin{array}{c}\text { t-test } \\
(p-v a l u e)\end{array}$ & $\begin{array}{c}\text { Excretion } \\
\left(\mu g \mathrm{NH}_{4}-\mathrm{N}\right. \\
\left.g^{-1} \mathrm{~h}^{-1}\right)\end{array}$ & $\begin{array}{c}\text { t-test } \\
(\bar{p} \text {-value })\end{array}$ & $\begin{array}{c}\mathrm{O} N \mathrm{~N} \\
\text { (Atomic } \\
\text { ratio) }\end{array}$ & $\begin{array}{c}\mathrm{t} \text {-test } \\
(\mathrm{p} \text {-value })\end{array}$ \\
\hline \multicolumn{11}{|l|}{1987} \\
\hline North Sea & 6 & $2.42 \pm 0.29$ & \multirow{2}{*}{0.43} & 0.60 & $0.95 \pm 0.19$ & \multirow{2}{*}{0.37} & $10.7 \pm 1.7$ & \multirow[t]{2}{*}{0.0006} & $75.7 \pm 6.4$ & \multirow{2}{*}{0.0062} \\
\hline Baltic Sea & 6 & $2.10 \pm 0.26$ & & 0.64 & $1.17 \pm 0.14$ & & $21.4 \pm 1.3$ & & $47.8 \pm 5.0$ & \\
\hline \multicolumn{11}{|l|}{1988} \\
\hline North Sea & 13 & $2.34 \pm 0.30$ & \multirow{2}{*}{0.0014} & 0.67 & $1.55 \pm 0.14$ & \multirow{2}{*}{0.44} & $106 \pm 6.2$ & \multirow{2}{*}{0.49} & $12.9 \pm 0.86$ & \multirow{2}{*}{0.054} \\
\hline Baltic Sea & 8 & $0.84 \pm 0.12$ & & 0.39 & $1.37 \pm 0.21$ & & $114 \pm 10.2$ & & $10.2=0.99$ & \\
\hline
\end{tabular}

transplanted mussels, although the differences between the two 1988 groups was not significant (p $<0.49)$. However, the resulting ratios of oxygen consumed to nitrogen excreted $(\mathrm{O} / \mathrm{N}$, in atomic equivalents) were lower for mussels transplanted from the Baltic than for North Sea mussels in both years, $75.7 \pm$ 6.4 and $47.8 \pm 5.0$ for native and transplanted mussels, respectively, in 1987 ( $p<0.0062$ ). For the smaller mussels used in 1988 the corresponding values were $12.9 \pm$ 0.86 and $10.2 \pm 0.99(p<0.054)$.

Native North Sea mussels were found to have higher clearance rates than transplanted Baltic Sea mussels in the 1988 experiment, although there was no significant difference in 1987 (Table 2). In 1988 the organic content of faeces was significantly higher in transplanted Baltic mussels, giving an absorption efficiency of only $39 \%$, compared to native North Sea mussels where it was $67 \%$. In 1987, after about 1 yr of acclimatisation, there appeared to be no differences and the food absorption efficiencies were $64 \%$ and $60 \%$, for Baltic and North Sea mussels, respectively.

The resulting energy budgets are summarized in Table 3, showing that 'scope for growth' was higher among mussels native to the North Sea during 1988, after 1 mo of acclimatisation, whereas in 1987, after 1 yr of acclimatisation, no significant differences could be shown.

The allele frequencies for Pgi and Pgm showed large differences between the parental Baltic and North Sea populations (Table 4), and the experimental mussels revealed a genetic composition similar to that of their parental populations (Johannesson et al. 1990).

\section{DISCUSSION}

Other studies have shown that the populations of Mytilus edulis from the Baltic and North Seas differ markedly both in morphological characteristics (Kautsky et al. 1990) and in physiological responses (Schlieper 1957, 1971, Lagerspetz \& Sirkka 1959, Lange 1972, Theede 1975, 1984, Tedengren \& Kautsky 1986). Tedengren \& Kautsky (1986) suggested that the lower growth rate and smaller maximum size of Baltic individuals are caused by a less favourable energy metabolism, demonstrated by consistently higher $\mathrm{NH}_{4}-\mathrm{N}$ excretion and lower $\mathrm{O} / \mathrm{N}$ ratios in Baltic mussels, due to physiological adaptations to the osmotic stress at low salinities. Although the detailed mechanisms are not yet fully understood, the most probable mechanism may be the acute salinity-dependent changes in amino acid metabolism and nitrogen excretion proposed by Tedengren \& Kautsky (1986).

The fact that growth in transplanted mussels approached that of the native populations (Kautsky et al. 1990) suggests that growth is mainly regulated by

Table 3. Mytilus edulis. Components of the energy budget $\left(\mathrm{J} \mathrm{g}^{-1} \mathrm{~h}^{-1}\right)$ in mussels transplanted from the Baltic Sea and acclimatised to North Sea conditions compared to mussels native to the North Sea. Comparisons within years only (means \pm SE)

\begin{tabular}{|c|c|c|c|c|c|c|c|}
\hline & $\begin{array}{l}\text { No. of } \\
\text { replicates }\end{array}$ & $\begin{array}{c}\text { Energy } \\
\text { consumed, } C\end{array}$ & $\begin{array}{c}\text { Energy } \\
\text { absorbed, A }\end{array}$ & $\begin{array}{l}\text { Energy } \\
\text { respired, } \mathrm{R}\end{array}$ & $\begin{array}{c}\text { Energy } \\
\text { excreted, U }\end{array}$ & $\begin{array}{l}\text { Scope for } \\
\text { growth }\end{array}$ & $\begin{array}{c}\text { t-test } \\
\text { (p-value) }\end{array}$ \\
\hline \multicolumn{8}{|l|}{1987} \\
\hline North Sea & 6 & $143.7 \pm 17.4$ & $86.2 \pm 10.4$ & $13.4 \pm 2.6$ & $0.208 \pm 0.033$ & $72.6 \pm 9.1$ & \multirow{2}{*}{0.40} \\
\hline Baltic Sea & 6 & $124.4 \pm 15.5$ & $79.6 \pm 9.95$ & $16.4 \pm 1.9$ & $0.415=0.026$ & $62.8 \pm 9.7$ & \\
\hline \multicolumn{8}{|l|}{1988} \\
\hline North Sea & 13 & $138.6 \pm 18.0$ & $93.1 \pm 12.1$ & $21.8 \pm 2.0$ & $2.05 \pm 0.12$ & $69.3 \pm 13.2$ & \multirow{2}{*}{0.0006} \\
\hline Baltic Sea & 8 & $49.8 \pm 20.5$ & $19.7 \pm 2.8$ & $19.1 \pm 8.2$ & $2.21 \pm 0.20$ & $-1.6 \pm 4.5$ & \\
\hline
\end{tabular}


Table 4. Allele frequency distributions of 2 enzyme loci for North Sea and transplanted Baltic Sea mussels used in the physiological tests in 1988. Allele frequencies of the parental populations are given as a comparison. (Allele designations as in Johannesson et al. 1990)

\begin{tabular}{|c|c|c|c|c|c|}
\hline \multirow{2}{*}{ Locus } & \multirow[t]{2}{*}{ Allele } & \multicolumn{2}{|c|}{ Parental populations } & \multicolumn{2}{|c|}{ Experimental populations } \\
\hline & & North Sea ${ }^{a}$ & Baltic Sea ${ }^{d}$ & North Sea & Baltic Sea \\
\hline \multirow[t]{6}{*}{$P_{g i}$} & 1 & 0.04 & 0.00 & 0.08 & 0.00 \\
\hline & 2 & 0.60 & 0.00 & 0.52 & 0.08 \\
\hline & 3 & 0.22 & 0.00 & 0.30 & 0.03 \\
\hline & 4 & 0.13 & 0.98 & 0.10 & 0.84 \\
\hline & 5 & 0.01 & 0.02 & 0.00 & 0.05 \\
\hline & $N$ & 46 & 52 & 20 & 19 \\
\hline \multirow[t]{6}{*}{$P g m$} & 1 & 0.00 & 0.09 & 0.00 & 0.10 \\
\hline & 2 & 0.03 & 0.85 & 0.05 & 0.66 \\
\hline & 3 & 0.26 & 0.06 & 0.22 & 0.08 \\
\hline & 4 & 0.65 & 0.00 & 0.70 & 0.16 \\
\hline & 5 & 0.05 & 0.00 & 0.02 & 0.00 \\
\hline & $N$ & 46 & 51 & 20 & 19 \\
\hline
\end{tabular}

short-term physiological adaptation to existing environmental differences. Acclimatisation is also indicated in the present study, where the physiological differences were larger in 1988, 1 mo after transplantation than in 1987, after the mussels had been adapting for more than $1 \mathrm{yr}$. However, the fact that some differences between the populations still remained 1 yr after transplantation would also indicate genetic causes.

While respiration rates were about the same in the populations, significant differences were obtained in $\mathrm{NH}_{4}-\mathrm{N}$ excretion which was 2 times higher for the Baltic mussels in 1987, resulting in lower $\mathrm{O} / \mathrm{N}$ ratios in these mussels. The differences remaining $1 \mathrm{yr}$ after transplantation were, however, smaller than those registered for native populations from the 2 salinity regimes by Tedengren \& Kautsky (1986) showing 2.5 to 3 times higher ammonia excretion for Baltic mussels at the lower ambient salinities. It was also shown that the ammonia excretion increased rapidly with lowered salinity and the resulting low $\mathrm{O} / \mathrm{N}$ ratio differed significantly between Baltic and North Sea populations. Although the transplanted mussels had a lower scope for growth than native mussels, this was only statistically significant after 1 mo of acclimatisation, but no longer after 1 yr. One of the main parameters explaining the lower scope for growth recorded for the Baltic mussels in 1988 was filtration rate. This parameter and food absorption efficiency often vary in opposite directions and a reduced food intake can be partially compensated by an increase in food absorption efficiency (Bayne et al. 1976a, Widdows 1978a). However, in the present study food absorption efficiency too was low in these mussels, amounting to only $58 \%$ of that of North Sea mussels. In the Baltic mussels acclimatised for $1 \mathrm{yr}$ in the high saline regime both filtration rate and food absorption efficiency were similar to that of native North Sea mussels.

As mentioned, the lower values for clearance rate and scope for growth of transplanted Baltic mussels were significant only in 1988, when they had been transferred 1 mo earlier, and probably were not yet fully acclimatised. After $1 \mathrm{yr}$ in the high saline regime, differences in these parameters were still present to a minor extent, although this was not statistically significant. The only statistically significant differences remaining after 1 yr were thus in $\mathrm{NH}_{4}-\mathrm{N}$ excretion and $\mathrm{O} / \mathrm{N}$ ratios.

Hence any genetic component seems to be very low, which is in accordance with Widdows et al. (1984), who found that physiological differences like clearance, respiration and excretion rates, absorption efficiency, $\mathrm{O} / \mathrm{N}$ and scope for growth, between 2 morphologically and physiologically distinct Mytilus edulis populations from an estuarine and a more stable marine site in Britain, were largely determined by environmental rather than by genotypic factors. It was also concluded that the mussels were fully acclimatised within 2 mo after transplantation, which is in accordance with Schlieper (1955) who found that enzymatic adaptation to variations in salinity may take 4 to $7 \mathrm{wk}$. Since much physiological variability is tied to spawning cycles, it should be mentioned here that the native North Sea mussels and transplanted Baltic mussels used in this study were all in the same stage of the reproductive cycle. All this suggests that the mussels examined 1 yr after transplantation in the 1987 study must have been fully acclimatised.

The fact, however, that some of the originally 
recorded differences, e.g. in morphology (cf. Kautsky et al. 1990), were maintained even after more than a year in the high saline North Sea regime suggests that part of the differences found between Baltic and North Sea populations of Mytilus edulis is not due to phenotypic adaptation to the salinity differences between the Baltic and North Seas, but is determined by genotypic factors. It can thus not be excluded that these genetic factors also influence physiological rates. Indirectly, this could be through a relatively smaller gill area in the more elongate Baltic-type mussels (cf. Kautsky et al. 1990), giving a lower clearance rate and thus lower scope for growth. These differences in shape would then also explain the fact that transplanted Baltic mussels have a lower biomass after 1 yr despite being of the same length as native North Sea mussels.

Genetic differentiation has been observed between mussels from the North Sea and Kattegat compared to individuals from the Baltic Sea (Theisen 1978, Bulnheim \& Gosling 1988, Varvio et al. 1988, Johannesson et al. 1990). The Baltic populations of the present study differed markedly from the North Sea populations in allele frequencies for Pgi and Pgm. The transferred Baltic populations were genetically similar to their parental population of Baltic mussels indicating that no or only slightly selective mortality occurred during the time of acclimatisation. Furthermore, Johannesson et al. (1990) found that populations from the Baltic were less genetically variable compared to North Sea populations in Pgi and Pgm, which were two of the loci which differed most. A positive relationship between multiple-locus enzyme heterozygosity and growth, or energy available for growth, has recently been demonstrated for a number of marine invertebrates including mussels (e.g. Singh \& Zouros 1978, Fujio 1982, Garton 1984, Garton et al. 1984, Koehn \& Gaffney 1984, Mitton \& Guant 1984, Diehl et al. 1985, Rodhouse et al. 1986). It has been argued that this relationship is due to a greater average efficiency of basal or standard metabolism in more heterozygous individuals (Koehn \& Shumway 1982, Garton 1984, Garton et al. 1984, Diehl et al. 1985). Although present results indicate that the main part of the growth differences between the Baltic and North Sea mussels seems to be non-genetic, a smaller part of the differences may be due to different genotypes.

After the present study was terminated (ca 16 mo after transplantation), the 1987 batch of Baltic mussels showed a very high late summer mortality (Kautsky et al. 1990). Tissue analysis of the transplanted Baltic mussels at this time showed that both those that died and those that survived were suffering from focal necrosis as well as severe infiltration of haemocytes to a higher extent than did native North Sea mussels (Tedengren \& Figueras unpubl.). Those that survived this period $(<0.5 \%)$ revealed, on the other hand, a marked differential survival for both $P g i$ and $P g m$ and the allele frequencies of these 2 loci became very similar to those of the North Sea population (Johannesson et al. 1990). This suggests that there may be longterm genetic effects on the physiological performance of the Baltic mussels transferred to a high saline environment. The fact that morphological differences like more elongate shells were maintained more than a year after transplantation of Baltic mussels (Kautsky et al. 1990), however, also indicates that genetic differences other than enzyme differences are present.

In conclusion, despite the presence of certain genetic differences, since both growth and physiological performance of transplanted Baltic Sea mussels approached that of native North Sea mussels, the results of this study support the conclusion of Johannesson et al. (1990) that Baltic and North Sea mussels are conspecific and that differences between populations are due to differential selection rather than distinct evolutionary backgrounds (Varvio et al. 1988).

Acknowledgement. We thank Dr K. Koop and 3 anonymous reviewers for valuable comments and Ms Wendy Symonds for linguistic corrections. The work was partly financed by grants from the Royal Swedish Acaderny of Sciences.

\section{LITERATURE CITED}

Bayne, B. L. (1973). Physiological changes in Mytilus edulis L. induced by temperature and nutritive stress. J. mar biol. Ass. U. K. 53: 39-58

Bayne, B. L., Brown, D. A., Burns, K., Dixon, D. R., Ivanovici, A., Livingstone, D. R., Lowe, D. M., Moore, M. N., Stebbing, A. R. D., Widdows, J. (1985). The effects of stress and pollution on marine animals. Preager Publishers, CBS Educational and Professional Publishing, New York

Bayne, B. L., Scullard, C. (1977). Rates of nitrogen excretion by species of Mytilus (Bivalvia: Mollusca). J. mar biol. Ass. U. K. $57: 355-369$

Bayne, B. L., Thompson, R. J., Widdows, J. (1976a). Physiology 1 In: Bayne, B. L. (ed.) Marine mussels. Cambridge University Press, Cambridge, p. 121-206

Bayne, B. L., Widdows, J., Thompson, R. J. (1976b). Physiological integrations. In: Bayne, B. L. (ed.) Marine mussels Cambridge University Press, Cambridge, p. 261-291

Bulnheim, H.-P., Gosling, E. (1988). Population genetic structure of mussels from the Baltic Sea. Helgoländer Meeresunters, 42: 113-129

Carleberg, S. (ed.) (1972). New Baltic Manual. Int. Coun. Explor. Sea (ICES) Coop. Res. Rep. Ser A 29: 1-145

Conover, R. J. (1966). Assimilation of organic matter by zooplankton. Limnol. Oceanogr. 11 338-354

Diehl, W. J., Gaffney, P. M., McDonald, J. H., Koehn, R. K. (1985). Relationship between weight-standardized oxygen consumption and multiple-locus heterozygosity in the mussel, Mytilus edulis. In: Gibbs, P. E. (ed.) Proc. 19th Eur Mar. Biol. Symp. Cambridge Univ. Press, Cambridge, p. $531-536$

Fujio, Y (1982). A correlation of heterozygosity with growth rate in the Pacific oyster, Crassostrea gigas. Tohoku J agric. Res. 33: 66-75 
Garton, D. W (1984). Relationship between multiple locus heterozygosity and physiological energetics of growth in the estuarine gastropod Thais haemastoma. Physiol. Zool. 57: $530-543$

Garton, D. W., Koehn, R. K., Scott, T M. (1984). Multiple locus heterozygosity and the physiological energetics of growth in the coot clam, Mulinia lateralis, from a natural population. Genetics 108: 445-455

Hawkins, A. J. S., Bayne, B. L., Day, A. J. (1986). Protein turnover, physiological energetics and heterozygosity in the blue mussel, Mytilus edulis: the basis of variable, agespecific growth. Proc. R. Soc. Lond. B 229: 161-176

Johannesson, K., Kautsky, N., Tedengren, M. (1990). Genotypic and phenotypic differences between Baltic and North Sea populations of the Mytilus edulis complex evaluated through reciprocal transplantations. II. Genetic variation. Mar. Ecol. Prog. Ser. 59: 211-219

Kautsky, N. (1982). Growth and size structure in a Baltic Mytilus edulis population. Mar. Biol. 68: 117-133

Kautsky, N., Johannesson, K., Tedengren, M. (1990). Genotypic and phenotypic differences between Baltic and North Sea populations of the Mytilus edulis complex evaluated through reciprocal transplantations. I. Growth and morphology. Mar. Ecol. Prog. Ser. 59: 203-210

Koehn, R. K., Diehl, W. J., Scott, T. M. (1988). The differential contribution by individual enzymes of glycolysis and protein catabolism to the relationship between heterozygosity and growth rate in the Coot Clam, Mulinia lateralis. Genetics 118: 121-130

Koehn, R. K., Gaffney, P. M. (1984). Genetic heterozygosity and growth rate in Mytilus edulis. Mar Biol. 82: 1-8

Koehn, R. K., Shumway, S. E. (1982). A genetic/physiological explanation for differential growth rate among individuals of the American oyster, Crassostrea virginica (Gmelin). Mar. Biol. Lett. 3: 35-42

Lagerspetz, K., Sirkka, A. (1959). Versuche über den Sauerstoffverbrauch von Mytilus edulis aus dem Brackwasser der finnischen Küste. Kieler Meeresforsch. 15: 89-96

Lange, R. (1972). Some recent work on osmotic, ionic, and volume regulation in marine animals. Oceanogr. mar. Biol. A. Rev. 10: $97-136$

Mitton, J. B., Grant, M. C. (1.984). Associations among protein heterozygosity, growth rate and developmental homeostasis. Ann. Rev. Syst. Ecol. 15: 479-499

Remane, A. (1971). Ecology of brackish water. In: Remane, A., Schlieper, C. (eds.) Biology of brackish water Wiley Interscience, New York, p. 1-210

Rodhouse, P. G., Gaffney, P. M. (1984). Effect of heterozygosity on metabolism during starvation in the American oyster Crassostrea virginica. Mar. Biol. 80: 179-187

Rodhouse, P. G., McDonald, J. H., Newell, R. I. E., Koehn, R. K. (1986). Gamete production, somatic growth and multiple-locus enzyme heterozygosity in Mytilus edulis. Mar. Biol. 90: 209-214

Schlieper, C. (1955). Über die physiologischen Wirkungen des Brackwassers. Kieler Meeresforsch. 11: 22-23

This article was submitted to the editor
Schlieper, C. (1957). Comparative study of Asterias rubens and Mytilus edulis from the North Sea $(30 \%)$ and the western Baltic Sea (15\%o). Année biol. 33: 117-127

Schlieper, C. (1971). Physiology of brackish water. In: Remane, A., Schlieper, C. (eds.) Biology of brackish water. Wiley Interscience, New York, p. 211-350

Singh, S. M., Zouros, E. (1978). Genetic variation associated with growth rate in the American oyster (Crassostrea virginica). Evolution 32: 342-352

Theede, H. (1975). Aspects of individual adaptation to salinity in marine invertebrates. In: Vernberg, F. J. (ed.) Physiological ecology of estuarine organisms. Univ. South Carolina Press, Columbia, p. 213-225

Theede, H. (1984). Physiological approaches to environmental problems of the Baltic. Limnologica, Berlin 15 (2): 443-458

Theisen, B. F. (1978). Allozyme clines and evidence for strong selection in three loci in Mytilus edulis L. (Bivalvia) from Danish waters. Ophelia 17: 135-142

Tedengren, M., Kautsky, N. (1986). Comparative study of the physiology and its probable effect on size in blue mussels (Mytilus edulis L.) from the North Sea and the northern Baltic proper Ophelia 25 (3) 147-155

Tedengren, M., Kautsky, N. (1987). Comparative stress response to diesel oil and salinity changes of Mytilus edulis from the North and Baltic Seas. Ophelia 28 (1): 1-9

Varvio, S.-L., Koehn, R. K., Väinölä, R. (1988). Evolutionary genetics of the Mytilus edulis complex in the North Atlantic region. Mar. Biol. 98: 51-60

Warren, C. E., Davis, G. E. (1967). Laboratory studies on the feeding, bioenergetics and growth of fish. In: Gerking, S. D. (ed.) The biological basis of freshwater fish production. Blackwell Scientific Publications, Oxford, p. 175-214

Widdows, J. (1978a). Combined effects of body size, food concentration and season on the physiology of Mytilus edulis. J. mar. biol. Ass. U. K. 58: 109-124

Widdows, J. (1978b). Physiological indices of stress in Mytilus edulis. J. mar. biol. Ass. U. K. 58: 125-142

Widdows, J., Donkin, P., Salkeld, P. N., Cleary, J. J., Lowe, D. M., Evans, S. V.. Thomson, P. E. (1984). Relative importance of environmental factors in determining physiological differences between two populations of mussels (Mytilus edulis). Mar. Ecol. Prog. Ser. 17: 33-47

Widdows, J., Johnson, D. (1988). Physiological energetics of Mytilus edulis: Scope for Growth. Mar. Ecol. Prog. Ser. 46: $113-121$

Widdows, J., Phelps, D. K., Galloway, W. (1981). Measurement of physiological condition of mussels transplanted along a pollution gradient in Narraganset Bay. Mar. envjron. Res. 4: 181-194

Winter, J. E. (1978). A review on the knowledge of suspension-feeding in lamellibranchiate bivalves, with special reference to artificial aquaculture systems. Aquaculture 13: $1-33$

Zouros, E., Singh, S. M., Miles, H. E. (1980). Growth rate in oysters: an overdominant phenotype and its possible explanations. Evolution 34: 856-867

Manuscript first received: April 14, 1989

Revised version accepted: September 28, 1989 